\title{
Analisis Kemampuan Pemahaman Konsep Matematis Siswa Kelas V Pada Materi Kubus Dan Balok
}

\author{
Huri Suhendri ${ }^{(i)}$ | Ike Fadilah
}

How to cite: Suhendri, H., \& Fadilah, I,. K Analisis Kemampuan Pemahaman Konsep Matematis Siswa Kelas V Pada Materi Kubus Dan Balok. International Journal of Progressive Mathematics Education. 1(2). 161-183. https://doi.org/10.22236/ijopme.v1i2.7308

To link to this article : https://doi.org/10.22236/ijopme.v1i2.7308

(C2021. The Author(s). This open access article is distributed under a Creative Commons Attribution (CC BY-SA) 4.0 license.

Sublished Online on Agustus 11, 2021




\title{
Analisis Kemampuan Pemahaman Konsep Matematis Siswa Kelas V Pada Materi Kubus Dan Balok
}

\author{
Huri Suhendri ${ }^{D}$ 1,2, Ike Fadilah $\varangle$ (D), \\ Received: February 8, $2021 \quad$ Accepted: July 27, 2021 Published Online: August 14, 2021
}

\begin{abstract}
Abstrak
Latar Belakang. Pemahaman konsep matematika menjadi fundamental dalam membangun pemahaman matematika yang komprehensif. Tujuan Penelitian untuk mendeskripsikan tingkat pemahaman konsep matematis siswa pada materi Kubus dan Balok. Penelitian juga akan menjelaskan bagaimana tahapan yang dilakukan oleh siswa sampai membentuk pemahaman konsep matematis pada materi kubus. Metode penelitian yang digunakan ialah penelitian kualitatif deskriptif dengan teknik sampling yang digunakan adalah purpose sampling. Subjek Penelitian dipilih dengan cara menyebarkan masalah matematika terlebih dahulu, lalu memilih subjek dengan kemampuan komunikasi yang baik. Dalam penelitian ini siswa yang memenuhi persayaratan sebanyak 32 orang. Hasil Penelitian menunjukkan bahwa kemampuan pemahaman konsep matematika siswa kelas $\mathrm{V}$ pada materi kubus dan balok tergolong dengan presentase paham konsep sebanyak $76 \%$, dan rata-rata kesalahan yang dilakukan siswa mencapai $24 \%$ tergolong rendah sebanyak 20 Subjek memperoleh nilai $\geq 75$ mewakili kategori kemampuan pemahaman konsep matematika tinggi Siswa berkemampuan tinggi mampu menguasai semua indikator dengan baik. Sebanyak 12 subjek memperoleh nilai < 75 mewakili kategori kemampuan pemahaman konsep matematika rendah tidak mampu menguasai semua indikator, siswa belum mampu memaparkan konsep yang bersifat sistematis.
\end{abstract}

Kata Kunci: Pemahaman Konsep Matematis, Kubus, Balok

(1) (1) 2021. The Author(s). This open access article is distributed under a Creative Commons Attribution (CC BY-SA) 4.0 license.

$\square$ Huri Suhendri,

huri.suhenderi@unindra.ac.id

Ike Fadilah

fadillah.ike03@gmail.com

1 Universitas Indraprasta PGRI Jakarta, Indonesia 


\section{PENDAHULUAN}

Sekolah Dasar merupakan sekolah pertama yang mendapatkan tumpuan besar dan harapan untuk dapat membekali kemampuan berpikir secara konsep dasar bagi diri anak. "Tujuan sekolah dasar ialah meletakkan dasar kecerdasan, pengetahuan, kepribadian, akhlak mulia, serta keterampilan untuk hidup mandiri dan mengikuti pendidikan lebih lanjut dengan demikian siswa dapat memiliki dan menanamkan sikap budi pekerti terhadap sesama (Hajar \& Mulyani, 2017). Dasar kecerdasan yang dimaksud dapat berupa kemampuan berpikir, baik secara konsep maupun secara operasional.

Untuk mewujudkan tujuan umum pendidikan dasar tersebut dapat ditempuh melalui mata pelajaran yang diajarkan setiap hari dalam proses pembelajaran di sekolah. Kelompok mata pelajaran yang dipelajari di sekolah dasar berdasarkan

Peraturan Pemerintah (PP) yang tertuang dalam Standar Isi bahwa kurikulum untuk jenis pendidikan umum, kejuruan, dan khusus pada jenjang pendidikan dasar dan menengah terdiri atas: 1) agama dan akhlak mulia; 2) kewarganegaraan dan kepribadian; 3) ilmu pengetahuan dan teknologi; 4) estetika; 5) jasmani, olah raga, dan kesehatan.

Mata pelajaran tersebut sudah diajarkan pada siswa kelas V Sekolah Dasar sesuai dengan kurikulum diatas dari 5 mata pelajaran yang tercantum pada standar nasional pendidikan terdapat kelompok mata pelajaran IImu pengetahuan dan Teknologi didalamnya terdapat mata pelajaran Matematika. Mata pelajaran matematika perlu diberikan kepada semua peserta didik mulai dari sekolah dasar untuk membekali peserta didik dengan kemampuan berpikir logis, analitis, sistematis, kritis, dan kreatif, serta kemampuan bekerja sama.(Nahdi, 2017)

Menurut Scheffer \& Markus (2016) Matematika sangat penting peranannya bagi kegiatan dalam kehidupan kita sehari-hari, Menyadari arti pentingnya matematika tersebut, maka matematika dirasakan perlu untuk dipahami dan dikuasai oleh segenap lapisan masyarakat, terutama siswa-siswa sekolah dasar hingga perguruan tinggi. hampir semua aktivitas berkaitan dengan konsep matematika dan banyak benda-benda disekitar kita berbentuk bangun geometri. misalnya pada materi bangun ruang sisi datar kubus dan balok. kesulitan siswa dalam penyelesaian soal matematika kubus dan balok dalam menghitung luas permukaan dan volume akibatnya siswa tidak bisa menyelesaikan soal tersebut dengan baik.

Akan tetapi mata pelajaran matematika masih ada yang menganggap bahwa matematika itu sulit. hal tersebut sesuai dengan pernyataan Aprilyani \& Hakim (2020: 62) Sebagian besar siswa 
menjadikan matematika sebagai mata pelajaran yang paling sulit dan menjadi hal yang menakutkan. Selain itu menurut Hevriansyah \& Megawanti, (2017:38) Matematika merupakan mata pelajaran yang kurang disenangi dan peserta didik sulit memahami serta mendapatkan nilai yang maksimal disebabkan kurangnya ketertarikan dalam belajar matematika. sehingga siswa tidak bisa menyelesaikan permasalahan matematika dengan benar. Indikasi rendahnya kemampuan pemahaman konsep ini ditandai oleh beberapa gejala bahwa sebagian siswa MI Attaqwa 28 Kota Bekasi belum bisa memilih prosedur atau operasi yang sesuai dalam menyelesaikan soal, siswa belum bisa mengaplikasikan konsep yang telah diajarkan jika diberikan soal cerita, siswa mengalami kesulitan dalam menyelesaikan soal yang modelnya sedikit berbeda dari contoh dan siswa kurang paham dalam menentukan hal-hal yang diketahui pada soal cerita dilihat dari hasil rata - rata Penilaian Tengah Semester sebagai berikut :

\section{Tabel 1 Hasil Penilaian Tengah Semester Tahun Pelajaran 2020/2021 (KKM:75)}

\begin{tabular}{ccccc}
\multirow{2}{*}{ No } & Rombel & \multicolumn{2}{c}{ Jumlah Peserta didik } & Rata - rata kelas \\
\cline { 3 - 4 } & & $\geq 75$ & $\leq 75$ & \\
\hline $\mathbf{1}$ & V-1 & 20 & 12 & 78,86 \\
\hline $\mathbf{3}$ & $\mathrm{V}-2$ & 13 & 19 & 68,38 \\
\hline $\mathbf{4}$ & $\mathrm{V}-3$ & 18 & 11 & 78,25 \\
\hline & V-4 & 19 & 10 & 77,12 \\
\hline
\end{tabular}

Sumber: Dokumentasi Tata Usaha MI Attaqwa 28

Matematika manekankan pada pemecahan suatu permasalahan, dimana masalah dalam matematika biasanya disajikan dalam bentuk soal matematika. Suatu pertanyaan akan menjadi masalah jika seseorang tersebut tidak mempunyai aturan tertentu. maka pemahaman konsep yang diajarkan pada tingkat dasar dapat dipergunakan untuk menemukan jawaban dari pertanyaan tersebut. menurut Muhandaz, dkk (2018) Pentingnya pemahaman konsep matematis dan besarnya peranannya dalam pembelajaran matematika, seharusnya kemampuan pemahaman konsep matematis sudah tertanam sejak dini dalam diri setiap siswa. maka dari itu perlu dibangun pada sekolah tingkat dasar mengenai pemahaman konsep matematis karena hal tersebut menjadi modal dasar untuk menyelesaikan persoalan matematika. sesuai dengan pernyataan Novitasari (2016) Pentingnya pemahaman konsep merupakan modal dasar atas perolehan hasil belajar yang memuaskan dievaluasi akhir nantinya(García \& Bosch, 2006; Maracci, 2008; Satriawati et al., 2018; Umam et al., 2019).

Hal tersebut.sesuai dengan pernyataan Zulhamma, (2020) "Dari beberapa materi bangun ruang tersebut, contohnya saja ketika siswa selesai mengerjakan soal luas permukaan dan volume 
siswa merasa kesulitan, dalam pemahaman konsep, penerapan prinsip dan keterampilan dalam pengerjaan soal". Hal tersebut sejalan degan pendapat Mutia (2017) siswa mengalami kesulitan dalam menguasai konsep kubus dan balok, menemukan rumus luas permukaan kubus balok, dan menggunakan rumus luas permukaan kubus dan balok. Kesulitan menggunakan rumus pada penyelesaian soal sebagai akibat dari menghafal rumus siap pakai, sehingga siswa sering lupa dengan rumus(Ferri, 2006; Radford, 2008; Sorvo et al., 2017).

Kemampuan pemahaman konsep matematis merupakan salah satu kemampuan yang harus dimiliki oleh siswa dalam pembelajaran matematika. kurangnya pemahaman konsep matematis menyebabkan siswa kesulitan dalam menyelesaikan soal matematika. Hal tersebut sesuai dengan pernyataan Ariyanto,dkk (2019) Kurangnya kemampuan pemahaman konsep matematis merupakan salah satu penyebab siswa kurang dalam menyelesaikan masalah suatu matematis. Memahami konsep matematika merupakan salah satu tujuan dari mata pelajaran matematika di sekolah. Berdasarkan pada studi pendahuluan dan hasil wawancara dengan guru dan siswa di Ml attaqwa 28 Kota Bekasi mengenai Ulangan Harian Bahwa ternyata nilai rata-rata hasil tes masih kurang memuaskan karena kurangnya pemahaman konsep matematis siswa menurut guru matematika disekolah tersebut. nilai rata-rata matematika kelas $\mathrm{V}$ dalam Ulangan Harian tahun ajaran 2020/2021 dapat dilihat tabel berikut :

\begin{tabular}{cccc} 
Tabel 2 & Nilai Rata-Rata dari Ulangan Harian Materi Skala & \\
No & Jumlah Siswa & Gender & Nilai Rata-Rata \\
\hline 1 & 60 & Laki-Laki & 58,7 \\
\hline 2 & 62 & Perempuan & 64,2 \\
\hline
\end{tabular}

Dari tabel tersebut terlihat dari siswa yang belajar di MI Attaqwa 28 Kota Bekasi menunjukan nilai rata-rata yang rendah jika dibandingkan nilai rata-rata Kriteria Ketuntasan Minimum (KKM) yang ditetapkan sekolah yaitu 75.

Berdasarkan permasalahan - permasalahan yang telah diuraikan, peneliti bermaksud melakukan penelitian dengan judul "Analisis Kemampuan Pemahaman Konsep Matematis Siswa Kelas V Pada Materi Kubus dan Balok".

\section{METODE PENELITIAN}

Metode yang dipilih pada penelitian ini yaitu metode kualitatif deskriptif. Alasan memilih metode kualitatif karena penelitian ini mendeskripsikan kata-kata tertulis atau lisan dari orangorang dan perilaku yang dapat diamati serta berusaha eksplorasi mendalam pada fenomena 
sentral tentang pemahaman konsep matematis pada siswa kelas 5 Sekolah Dasar(Galbraith \& Stillman, 2006; Lean \& Clements, 1981; Tan, 2018). Metode penelitian kualitatif digunakan untuk meneliti pada kondisi objek yang alamiah dimana peneliti adalah sebagai instrumen kunci, dan hasil penelitian kualitatif lebih menekankan makna daripada generalisasi (Mulyadi, 2011, 131).

\section{Rencana Penelitian}

Dalam suatu penelitian perlu ada desain penelitian yang sesuai dengan variabelvariabel yang terkandung dalam tujuan penelitian untuk diuji kebenarannya. Desain penelitian merupakan rancangan tentang cara menganalisis data agar dapat dilaksanakan secara ekonomis dan sesuai dengan tujuan penelitian. Desain penelitian yang digunakan dalam penelitian ini menggunakan pendekatan kualitatif dan jenis penelitian yang digunakan adalah penelitian deskriptif. Adapun langkah-langkah rancangan yang disusun adalah sebagai berikut.

a. Menetapkan subjek penelitian

b. Melakukan observasi

c. Melakukan pengamatan terhadap pelaksanakan pembelajaran secara daring penelitian menggunakan model pembelajaran discovery learning.

d. Melaksanakan instrumen tes untuk mengetahui kemampuan pemahaman konsep siswa dikelas penelitian.

e. Melaksanakan wawancara

f. Mengolah dan menganalisis data yang telah dikumpulkan

g. Menyusun hasil penelitian.

\section{Subjek Penelitian}

Subjek dalam penelitian ini sampel yang diambil yaitu siswa kelas V.2 di MI Attaqwa 28 Kota Bekasi, sebanyak 32 orang,. Dengan Informannya adalah 1 Guru Matematika kelas V dan Walikelas kelas V.2

Dalam penelitian ini peneliti mengambil sampel dengan menggunakan teknik purposive sampling menurut Maharani dan Bernard $(2018,822)$ purposive sampling adalah teknik penentuan sampel dengan pertimbangan tertentu. Artinya setiap subyek yang diambil dari populasi dipilih dengan sengaja berdasarkan tujuan dan pertimbangan tertentu. Pertimbangan-pertimbangan yang dilakukan dalam teknik purposive sampling ini bisa beragam dan tergantung pada kebutuhan dari penelitian yang akan dilakukan.

\section{Instrumen Penelitian}




\section{Tes}

Instrumen penelitian berupa instrument tes yang terdiri dari 10 butir soal yang disusun berdasarkan indikator pemahaman konsep dan kemampuan pemecahan masalah matematis, yaitu soal kontektual yang mengambil pokok bahasan Volume Bangun Ruang Kubus dan Balok. Kisi-kisi instrumen kemampuan pemahaman konsep matematika yang akan disajikan pada bagian ini digunakan untuk memberikan informasi mengenai butir-butir soal yang diberikan kepada sampel.

\section{Tabel 3 Kisi-kisi Instrumen Kemampuan Pemahaman Konsep Matematika}

\section{Aspek Kemampuan}

Indikator

Pemahaman konsep

$$
\text { matematis }
$$

$\begin{array}{llll}1 & 2 & 3 & 4\end{array}$

Siswa dapat memahami kegiatankegiatan sehari-hari berkaitan dengan volume kubus dan balok

Siswa dapat mencermati cara menentukan mengamati konteks dalam kehidupan di sekitar yang terkait dengan volume kubus dan balok

Siswa dapat menyelesaikan permasalahan kontekstual dengan volume kubus dan balok.

\section{Keterangan Aspek Kemampuan Pemahaman Konsep:}

1. Memahami masalah,

2. Memberikan contoh, meringkas sesuai pemahaman siswa,

3. Mengklasigfikasikan berbedaan kubus dengan balok

4. Menjelaskan apa yang telah dipahami.

Adapun materinya adalah mengenai pokok bahasan Volume Balok dan Kubus. Dari 10 butir soal yang disusun, masing-masing soal ditetapkan untuk skor minimal nol dan skor maksimal sepuluh. Kemudian, secara teknis untuk pemberian skor tes pada kemampuan pemahaman konsep matematis dilakukan Hamzah (2014: 149) yaitu sebagai berikut:

\section{Tabel 4 Pedoman Penskoran Tes Kemampuan Pemahaman Konsep Matematika}

Indikator Pemahaman Matematika dan Rincian Jawaban

Skor

Pemahaman rasional, fungsional, relasional: mengidentifikasi kaitan antar konsep/prinsip, melaksanakan perhitungan disertai dengan alasan terhadap proses matematika yang dilakukan 


\begin{tabular}{llc}
\hline 1. & Tidak ada jawaban & 0 \\
\hline 2. & $\begin{array}{l}\text { Mengidentifikasi data/konsep/prinsip yang termuat dalam informasi yang } \\
\text { diberikan }\end{array}$ & $0-2$ \\
\hline 3. & $\begin{array}{l}\text { Mengaitkan konsep/prinsip yang satu dengan yang lainnya dan } \\
\text { menyatakannya dalam simbol matematik }\end{array}$ & $0-2$ \\
\hline 4. & $\begin{array}{l}\text { Melaksanakan perhitungan terhadap proses matematika yang dilakukan } \\
\text { disertai dengan menyertakan konsep/prinsip/aturan yang digunakan pada tiap } \\
\text { langkah pengerjaan }\end{array}$ & $0-2$ \\
\hline 5. & $0-2$ \\
\hline 6enetapkan solusi akhir disertai dengan alasan & Sub-total (satu butir tes) & $0-8$ \\
\hline
\end{tabular}

2. Pedoman Wawancara

Berikut adalah daftar pertanyaan wawancara yang .dilakukan oleh peneliti terhadap guru dalam bidang matematika dalam studi pendahuluan:

1) Apa saja kendala yang ibu alami selama mengajarkan matematika kepada siswa?

2) Apakah mereka menyukai pelajaran matematika?

3) Bagaimana karakteristik peserta didik kelas V.2 dalam Proses belajar matematika?

4) Materi apa yang paling dianggap sulit dari pelajaran matematika dikelas $V$ ini?

5) Bagaimana cara ibu menanggani siswa yang mangalami kesulitan matematika pada materi bangun ruang sisi datar?

6) Bagaimana reaksi siswa ketika ibu memberikan soal yang berbeda dengan contoh?

7) Bagaimana kemampuan pemahaman konsep matematika siswa dalam proses pembelajaran?

8) Pada Saat belajar matematika, apakah banyak dari siswa yang lebih cenderung menghapalkan rumus dibandingkan dengan memahami konsep dasar?

9) Metode apa yang biasa ibu gunakan dalam mengajar matematika di kelas pada pandemi covid 19 sekarang ini?

Selanjutnya setelah mengetahui faktor-faktor yang mempengaruhi kemampuan pemahaman konsep matematis peserta didik yang didapat melalui wawancara terhadap guru matematika yang perlu dilakukan yaitu menyusun Pedoman wawancara berdasarkan indikator kemampuan pemahaman konsep matematis yang ditujukan kepada siswa yaitu:

1. Apakah anda memahami penjelasan yang disampaikan guru ?

2. Apakah anda antusias mengikuti pembelajaran ? 
3. Apakah anda merasa terbebani dengan kemampuan minimal yang harus dikuasai $?$

4. Apakah anda terbantu dengan teman anda ketika anda mengalami kesulitan ?

5. Berapa persenkah pemahaman anda dari penjelasan guru ?

6. Apa saja kesulitan yang anda alami pada materi bangun ruang kubus dan balok ?

3. Pedoman Dokumentasi

Teknik pengumpulan data dengan pedoman dokumentasi ialah pengambilan data yang diperoleh melalui dokumen-dokumen. Menurut Villela (2020:149) Metode dokumentasi berarti cara mengumpulkan data dengan mencatat data-data yang sudah ada. Metode ini lebih mudah dibandingkan dengan metode pengumpulan data yang lain. Sedangkan menurut Sugiyono (2015) dokumen merupakan catatan peristiwa yang sudah berlalu. Dokumen bisa berbentuk tulisan, gambar, atau karya-karya monumental dari seseorang. Dokumen yang tulisan misalnya catatan harian, sejarah kehidupan (life histories), ceritera, biografi, peraturan, kebijakan. Dokumen yang berbentuk gambar, misalnya foto, gambar hidup, sketsa dan lainlain Data-data yang dikumpulkan dengan teknik dokumentasi cenderung merupakan data sekunder. Artinya, data pelengkap yang diperoleh tidak melalui tangan pertama, melainkan melalui tangan kedua, ketiga atau seterusnya. Perkecualian juga pada riset kuantitatif. Sedangkan. data-data yang dikumpulkan dengan teknik observasi dan wawancara cenderung merupakan data primer atau data yang langsung didapat dari pihak pertama

\section{Metode Pengumpulan Data}

\section{a. Sumber Data}

1. Siswa kelas V.2 MI Attaqwa 28 Kota Bekasi sebanyak 32 orang dengan 17 orang lakilaki dan 15 orang perempuan sebagai sumber data peneliti

2. Guru dalam penelitian ini sebagai informan, diantaranya Guru Matematika dan walikelas V.2

3. Dokumentasi dalam penelitian ini digunakan untuk menyimpan data-data dokumentasi di lapangan penelitian yaitu berupa data-data statistik sekolah maupun foto-foto yang diperoleh saat proses penelitian berlangsung, serta hasil wawancara kepada informan.

\section{Analisis Data}

Analisis data Kualitatif adalah proses mencari dan menyusun secara sistematis data yang diperoleh dari hasil wawancara, catatan lapangan, dan bahan-bahan lain, sehingga dapat mudah dipahami, dan temuannya dapat diinformasikan kepada orang lain (Villela, 2020). Analisis data 
dilakukan dengan mengorganisasikan data, menjabarkannya ke dalam unit-unit, melakukan sintesa, menyusun ke dalam pola, memilih mana yang penting dan yang akan dipelajari, dan membuat simpulan yang dapat diceriterakan kepada orang lain.

Analisis kualitatif, data yang muncul berwujud kata-kata dan bukan rangkaian angka. Data itu mungkin telah dikumpulkan dalam aneka macam cara yaitu pengamatan terlibat, wawancara, dan selanjutnya diproses melalui perekaman, pencatatan, pengetikan, tetapi analisis kualitatif tetap menggunakan kata-kata yang biasanya disusun ke dalam teks yang diperluas.

Miles dan Huberman (dalam Sugiyono, 2018, 246), mengemukakan bahwa aktifitas dalam analisis data kualitatif secara interaktif dan berlangsung secara terus menerus sampai tuntas, sehingga datanya jenuh. Ukuran kejenuhan data ditandai dengan tidak diperolehnya lagi data atau informasi baru. Aktifitas dalam analisis data kualitatif model Miles dan Huberman ada tiga (3) tahap yaitu meliputi reduksi data (data reduction), penyajian data (data display), serta penarikan kesimpulan/verifikasi (conclusion drawing/verification).

a. Reduksi Data ( Data Reduction)

Data yang diperoleh dari penelitian dilapangan jumlahnya cukup banyak, untuk itu perlunya dicatat lagi secara terperinci dan sistematis. Mereduksi data berarti merangkum, meringkas, memilih hal-hal yang pokok, dan memfokuskan pada hal-hal penting (Riswani dan Widayati, 2012, 11). Oleh karena itu maka data yang direduksi dapat membantu peneliti dalam pengumpulan data selanjutnya.

Dalam mereduksi data ini peneliti menggunakan teknik triangulasi. Triangulasi adalah teknik penggabungan (Hadi dan Rulviana, 2018,65). Triangulasi diartikan sebagai teknik pengumpulan data yang bersifat menggabungkan dari berbagai teknik pengumpulan data dan sumber data yang telah ada. Tujuan dari triangulasi itu sendiri adalah untuk meningkatkan pemahaman dari peneliti terhadap apa yang diperoleh dari hasil penelitian. Teknik triangulasi ini dilakukan secara terus menerus sampai peneliti mendapatkan data yang dibutuhkan. Dalam penelitian ini peneliti menggunakan teknik tringulasi dikarenakan peneliti menggunakan teknik pengumpulan data yang berbeda-beda, seperti obsevasi, wawancara, dan pemberian tes untuk mendapatkan data dari sumber yang sama.

\section{b. Penyajian Data (Data Display)}

Pada tahap ini banyak yang terlibat dalam kegiatan penyajian (display) dari data yang dikumpulkan dan dianalisis sebelumnya, mengingat bahwa peneliti kualitatif banyak menyusun data naratif dan desktiptif. Miles dan Huberman (dalam Sugiyono, 2018: 249), menyatakan "the 
most frequent form of display data for qualitative research data in the post has been narrative text" yang paling sering digunakan untuk menyajikan data dalam penelitian kualitatif adalah dengan teks yang bersifat naratif'. Display adalah format yang menyajikan informasi secara tematik kepada pembaca dengan menggunakan tabel, grafik, atau semacamnya, bukan diisi dengan angka-angka melainkan dengan kata-kata. Data yang disajikan akan membantu peneliti untuk memahami apa yang terjadi, sehingga peneliti dapat merencakan penelitian selanjutnya berdasarkan apa yang telah dipahami tersebut.

c. Pengambilan Kesimpulan / Verifikasi (Conclusing Drawing / Verification)

Langkah selanjutnya dalam analisis data kualitatif ini ialah pengambilan kesimpulan berdasarkan temuan dan verifikasi data. Kesimpulan dalam penelitian kualitatif bisa dikatakan dapat menjawab rumusan masalah yang dirumuskan diawal, tapi ini juga tidak memungkinkan hal itu terjadi, karena seperti yang telah dikemukakan bahwa masalah dan rumusan masalah dalam penelitian kualitatif bersifat sementara dan akan berkembang setelah peneliti melakukan penelitian dilapangan. Kesimpulan penelitian kualitatif ini akan menjadi temuan/hasil baru dari yang sebelumnya pernah ada, temuan ini bisa berupa deskripsi atau gambaran suatu objek yang sebelumnya masih abu-abu atau gelap tetapi setelah diteliti menjadi cerah dan jelas.

\section{HASIL DAN PEMBAHASAN}

Penelitian dengan judul "Analisis Pemahaman Konsep Matematika siswa kelas V pada pokok bahasan Bangun Ruang Kubus dan Balok Tahun Pelajaran 2020/2021" merupakan sebuah penelitian yang dilakukan untuk mengetahui kemampuan pemahaman konsep siswa pada materi Bangun Ruang Kubus dan Balok. Indikator yang digunakan dalam penelitian ini adalah menghitung besar volume dari bangun ruang kubus dan balok untuk mempresentasikan suatu konsep, mengidentifikasi membuat contoh dan bukan contoh, mengubah suatu bentuk representasi ke bentuk lain, mengidentifikasi sifat-sifat suatu konsep, membandingkan dan membedakan konsepkonsep, dan mengenal syarat-syarat yang menentukan suatu konsep berdasarkan teori Hendarsih.

\section{Data Hasil Tes}

Berdasarkan hasil secara umum, hampir semua siswa dapat menyelesaikan nomor 1, semua siswa mampu menyelesaikan dengan baik dan benar. hanya aja perbaikan dalam pola menggambar bangun ruang yang masih harus diperhatikan. 


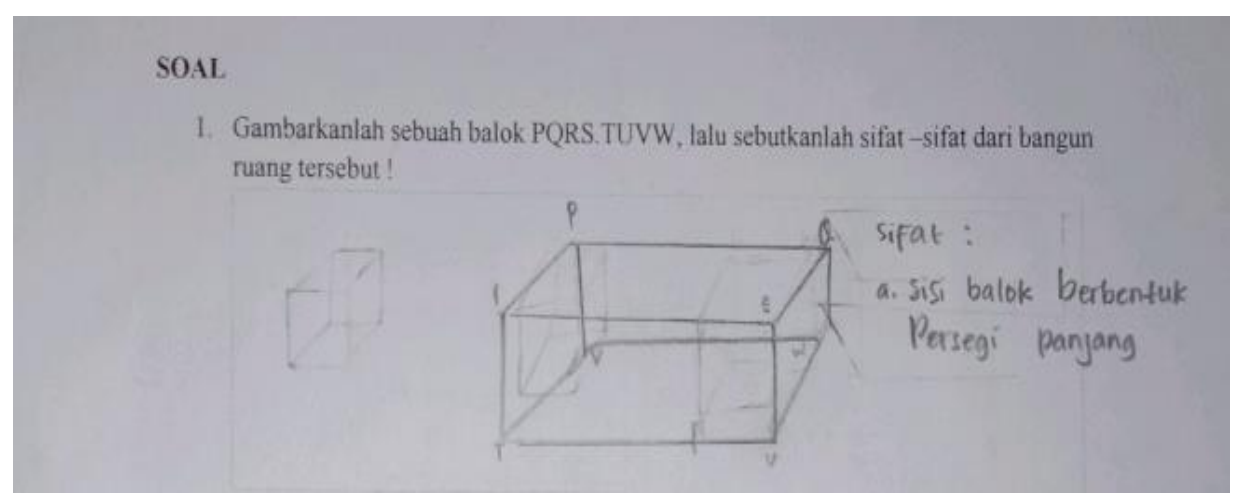

Gambar 1:Hasil Jawaban Siswa

Pada soal nomor 2, 30 siswa mampu menyelesaikan dengan baik dan benar. Namun, ada pula yang tidak dapat menyelesaikan dengan baik, dikarenakan belum dapat menggambar kubus dengan baik dan benar.

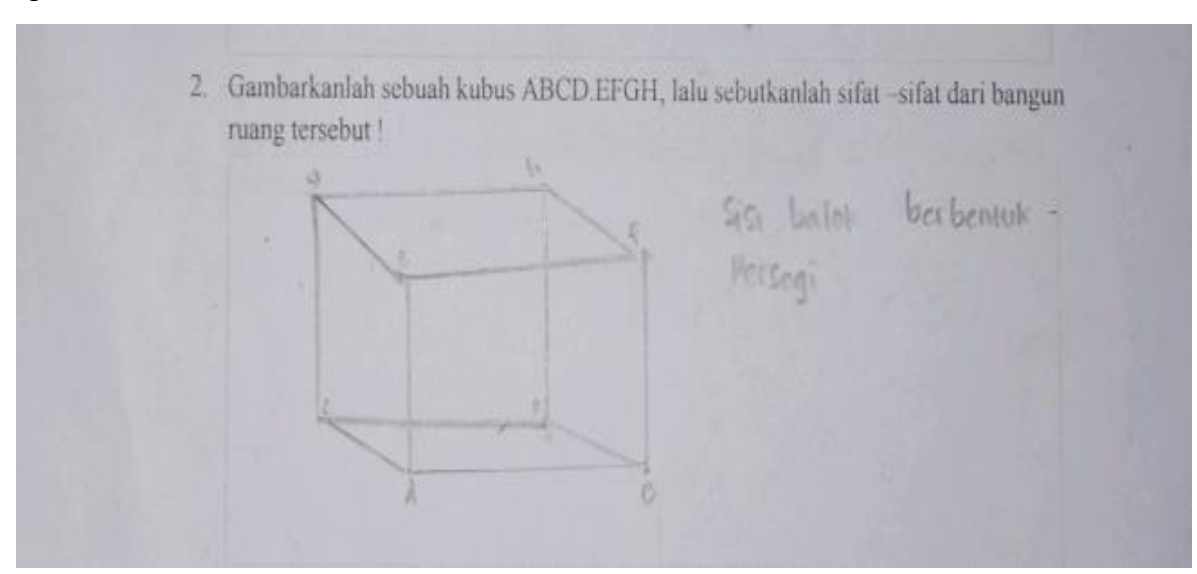

\section{Gambar 2: Hasil jawaban siswa yang belum dapat menggambar dengan benar}

Pada nomor 3, seluruh siswa yang dapat mengerjakan dengan baik dan benar. Soal yang terdapat di soal tersebut, menurut wawancara dengan siswa, soal dengan indikator 3 termasuk soal yang sangat mudah. 


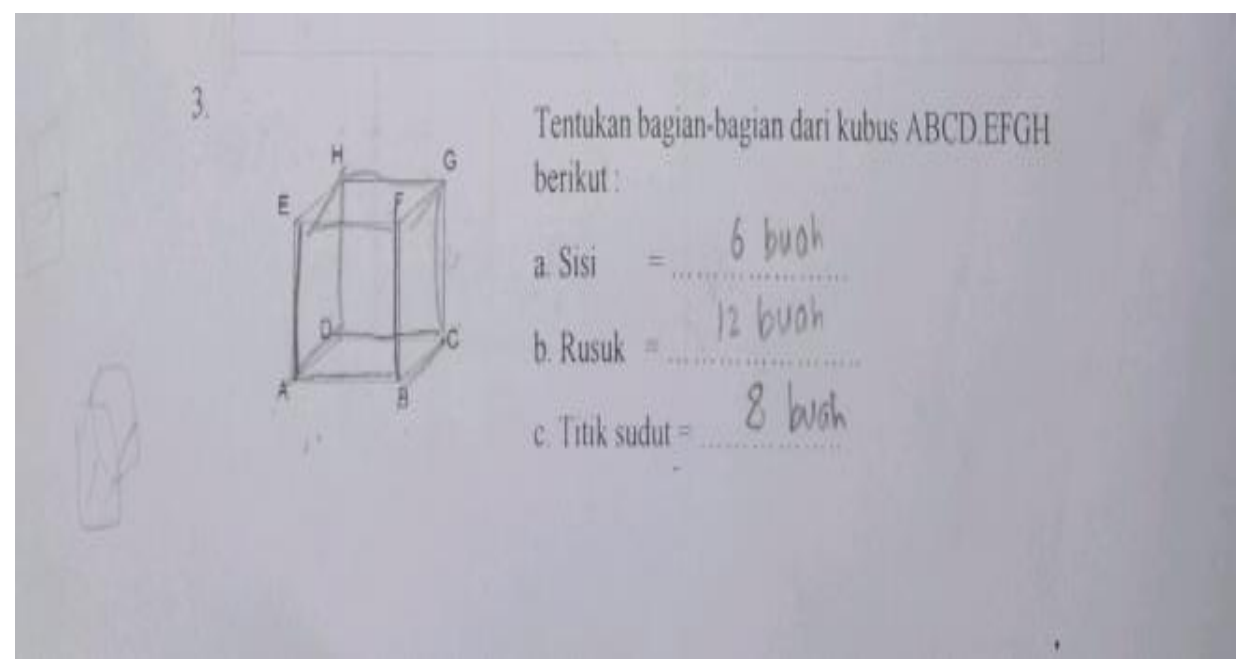

\section{Gambar 3:Hasil jawaban siswa yang benar}

Pada soal nomor 4, 20 siswa dapat menyelesaikan nomor 4, dengan baik dan benar. Namun, 12 siswa yang tidak dapat menyelesaikan dengan baik dan benar. karena kurang teliti dalam membaca soal.

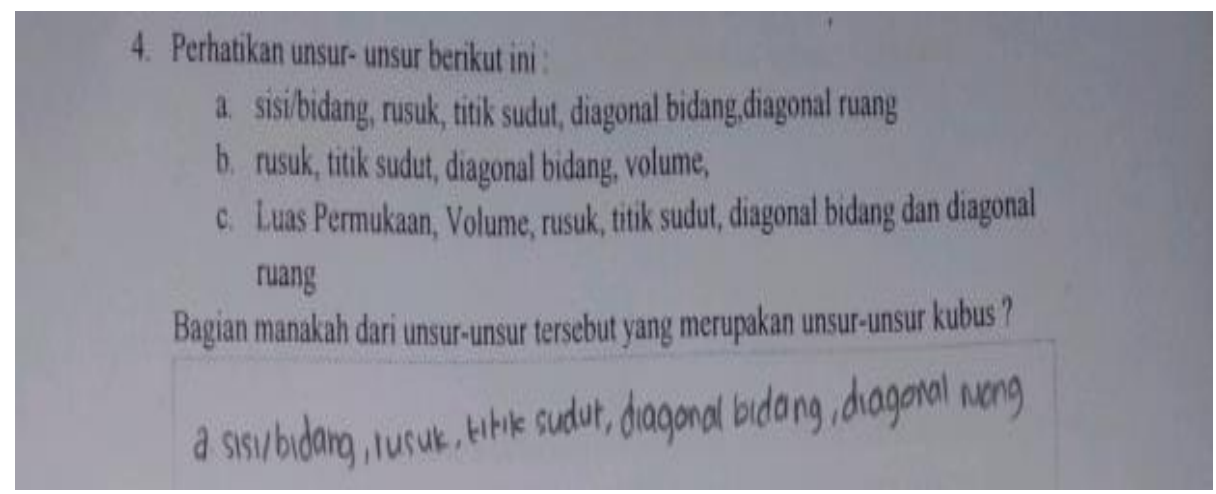

\section{Gambar 4: Hasil jawaban siswa yang benar}

Pada soal nomor 5, 22 siswa dapat menyelesaikan nomor 5, dengan baik dan benar. Namun, masih ada pula yang tidak dapat menyelesaikan dengan baik dan benar dalam proses menggambar jarring-jaring kubus 


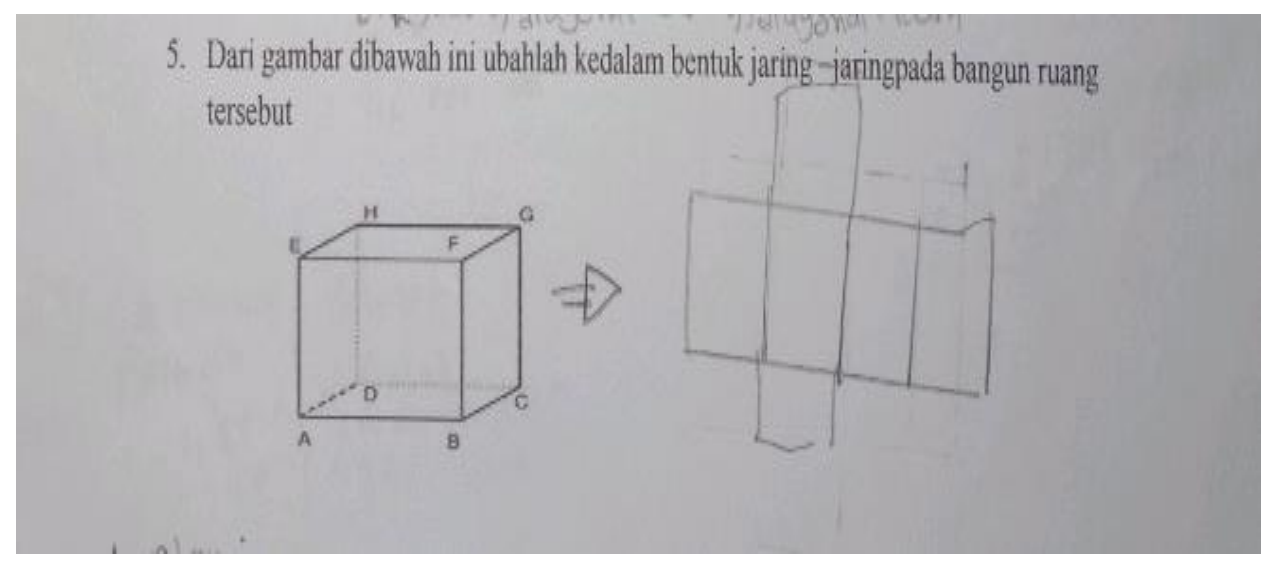

Gambar 5: Hasil jawaban siswa yang salah

Pada soal nomor 6, 20 siswa yang dapat mengerjakan dengan baik dan benar. Namun, ada pula yang tidak dapat menyelesaikan dengan baik karena kesulitan dalam proses menggambar.

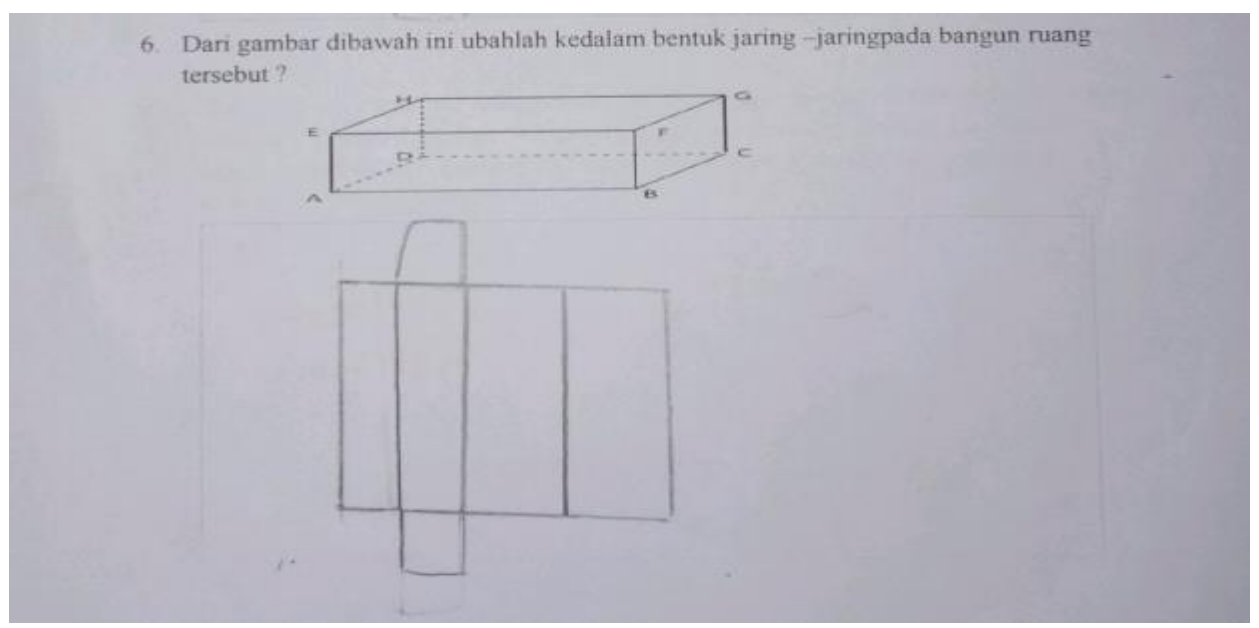

\section{Gambar 6: Hasil jawaban siswa yang mengalami kesulitan dalam menggambar}

Pada soal nomor 7, 22 siswa yang dapat menyelesaikan dengan baik dan benar, dalam proses penyelesaian masih banyak siswa yang tidak membuat rincian yang sudah diketahui dari soal. 


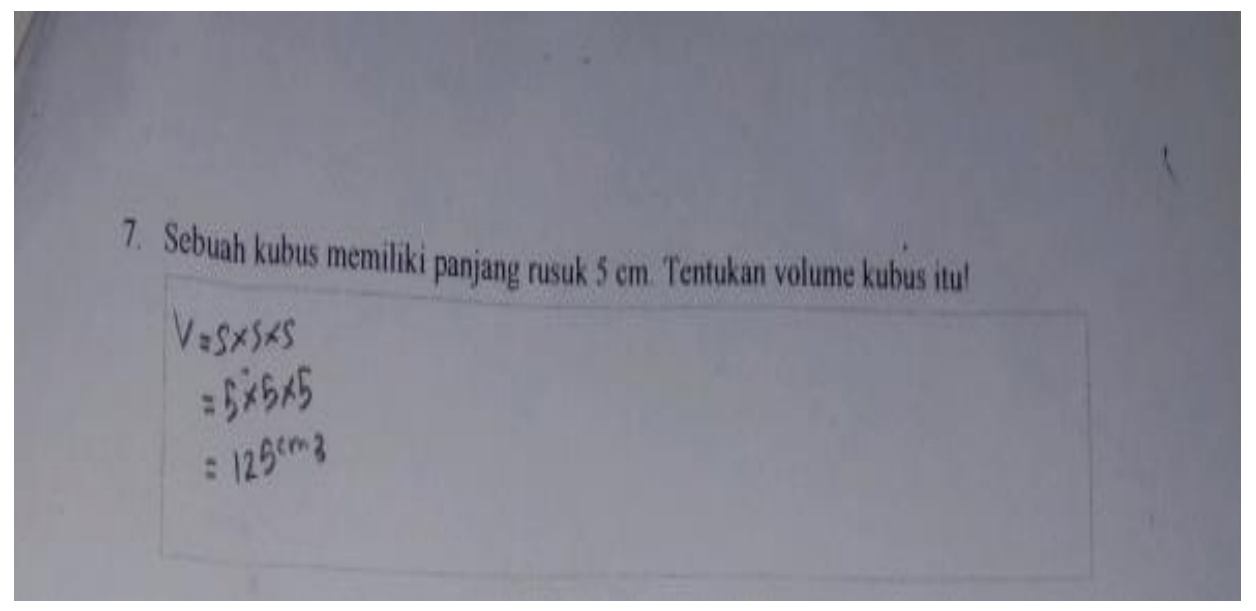

\section{Gambar 7:Hasil jawaban siswa yang tidak menyelesaikan secara konsep matematika}

Pada no 8, 20 siswa siswa yang dapat menyelesaikan dengan baik dan benar, tetapi masih ada siswa yang belum menyelesaikan dengan baik karenaa kurang teliti dalam membaca soal.

8. Safril sedang membersihkan akuarium di rumlahnya. Akuarium Safril berbentuk kubus dengan panjang rusuk $60 \mathrm{~cm}$. Safril kemudian mengisi akuariumnya dengan air sampai penuh. Berapakah volume air dalam akuarium tersebut?

$$
\begin{aligned}
& \text { di kefuhui }=S=60^{\mathrm{Cm}} \\
& \text { Jawuball: } \\
& V=5 \times 5 \times 5 \\
&=60 \times 60 \times 60 \\
&=216600 \mathrm{~cm}^{3}
\end{aligned}
$$

\section{Gambar 8:Hasil jawaban siswa}

Pada soal no 9, 28 siswa dapat menyelesaikan soal dengan baik dan benar. dari jenis soal menghitung volume indicator soal no 9 tergolong cukup mudah. Namun, masih ada beberapa siswa yang belum dapat menyelesaikan soal tersebut. 


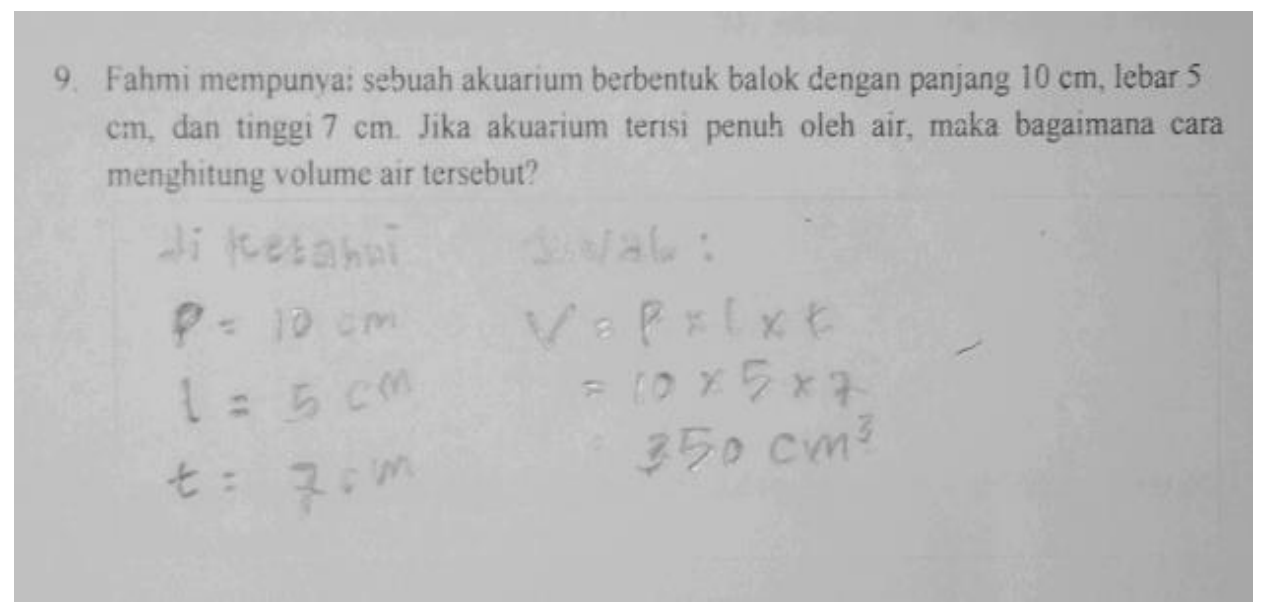

\section{Gambar 9: hasil jawaban siswa}

Pada soal no 10, 19 siswa menyelesaikan soal dengan baik dan benar, Tetapi, masih ada beberapa siswa yang belum dapat menyelesaikan soal tersebut karena belum memahami maksud dari soal tersebut.

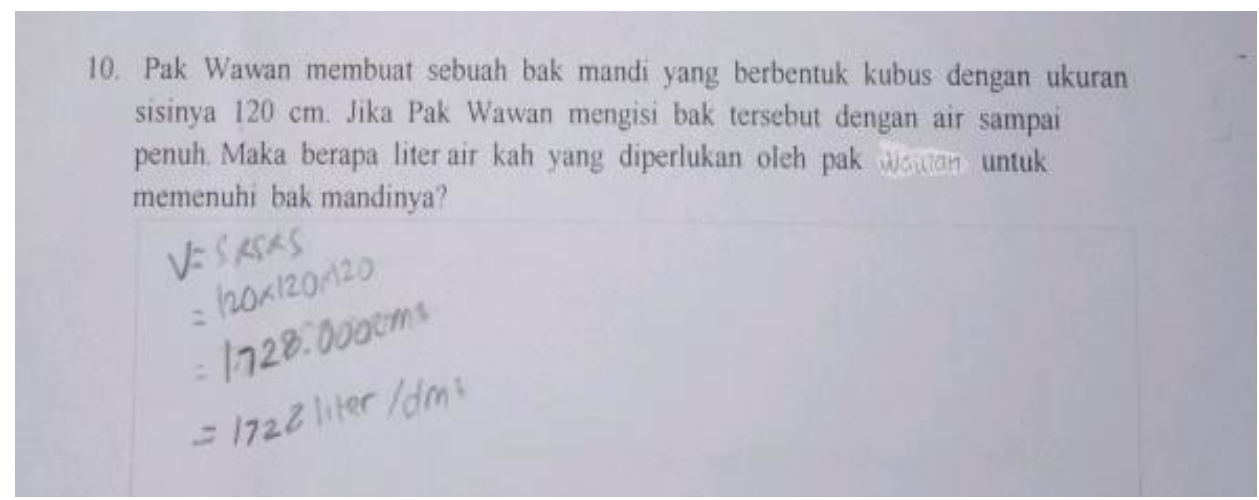

\section{Gambar 10: hasil jawaban siswa}

Dari jawaban siswa tersebut dapat dilihat adanya keberagaman jawaban yang didapat, tetapi untuk poin pentingnya pada tahap memahami konsep matematis ini mayoritas siswa sudah mampu memahaminya dengan baik. Seperti yang terlihat pada soal-soal yang diberikan terdapat 2 nomor yang dijawab dengan sempurna dalam tahap memahami konsep, hal ini tampak pada keterangan bahwa siswa mampu mengidentifikasi syarat-syarat apa saja yang diketahui dalam soal dan hal apa saja yang ditanyakan dalam soal tersebut. Sedangkan pada gambar 7,8,9,dan 10 masih banyak siswa yang tidak menjabarkan apa saja yang diketahui dan ditanyakan pada soal. 
Berdasarkan hasil penelitian, didapat bahwa penggunaan pembelajaran discovery learning yang diterapkan pada proses pembelajaran menunjukkan kemampuan pemahaman konsep matematika siswa memiliki perkembangan yang baik. Data hasil tes kemampuan pemahaman konsep matematika siswa kelas V.2 yang diikuti 32 siswa. Dari hasil penelitian terhadap soal-soal yang diberikan kepada subjek sebanyak 10 butir soal berbentuk uraian (essay). Berikut terlampir hasil tes kemampuan pemahaman konsep matematis

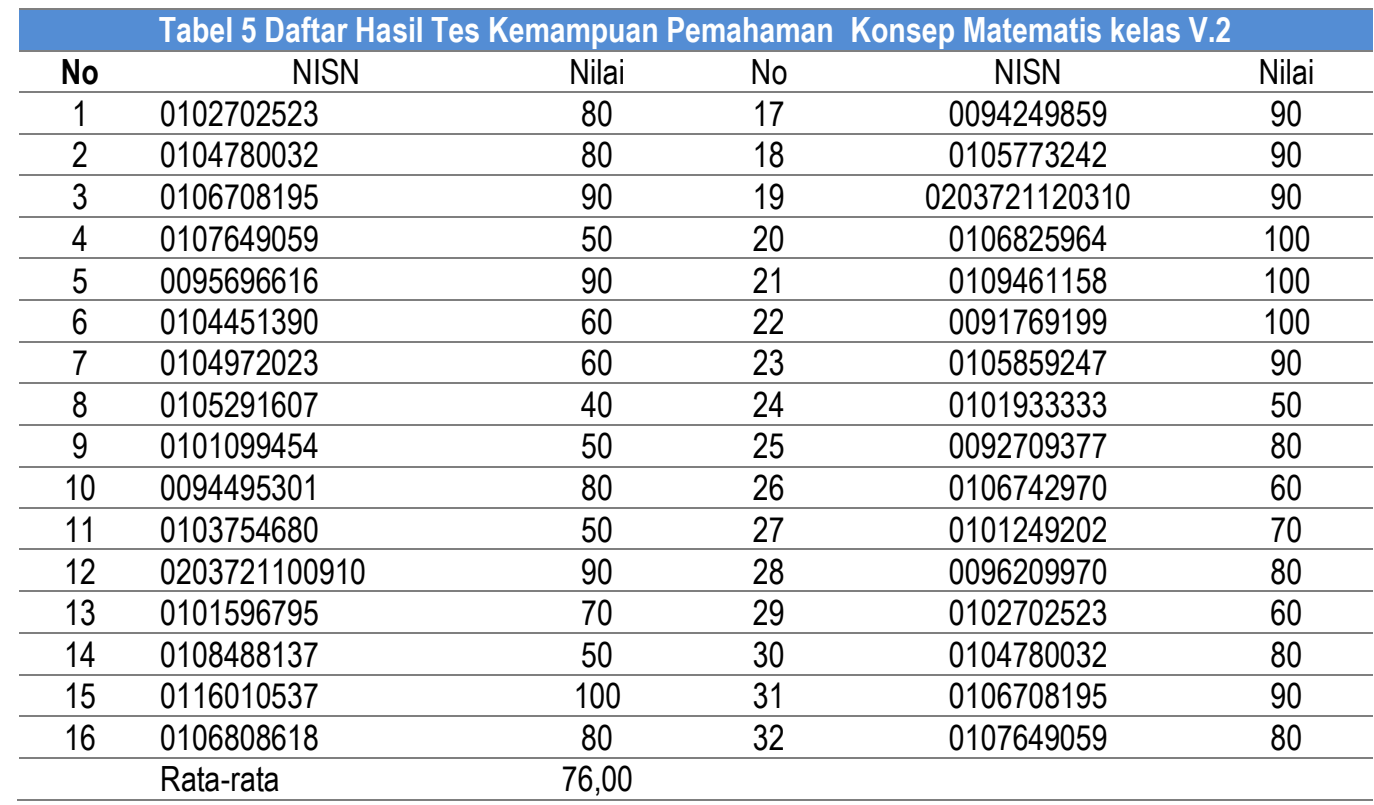

\begin{tabular}{|c|c|c|c|}
\hline \multicolumn{4}{|c|}{ Tabel 6 Tabel Distribusi Frekuensi } \\
\hline No & Nilai & f & Kategori \\
\hline 1 & $31-40$ & 1 & Kurang \\
\hline 2 & $41-50$ & 5 & Kurang \\
\hline 3 & $51-60$ & 4 & Cukup \\
\hline 4 & $61-70$ & 2 & Baik \\
\hline 5 & $71-80$ & 8 & Amat Baik \\
\hline 6 & $81-90$ & 8 & Amat Baik \\
\hline 7 & $91-100$ & 4 & Istimewa \\
\hline & Jumlah & 32 & \\
\hline
\end{tabular}

Selanjutnya nilai rata-rata pemahaman konsep tersebut diinterpretasikan dengan menggunakan tabel 1 berikut ini:

\section{Tabel 7}

\section{Interpretasi Nilai Rata-Rata}

\begin{tabular}{lll}
\hline No & Nilai & Kriteria \\
\hline
\end{tabular}




\begin{tabular}{ccc}
\hline $\mathbf{1}$ & $\geq 95,00$ & Istimewa \\
\hline $\mathbf{2}$ & $94,99-80,00$ & Amat Baik \\
\hline $\mathbf{3}$ & $79,99-65,00$ & Baik \\
\hline $\mathbf{4}$ & $64,99-55,00$ & Cukup \\
\hline $\mathbf{5}$ & $54,99-40,00$ & Kurang \\
\hline $\mathbf{6}$ & $<40,00$ & Amat Kurang \\
\hline
\end{tabular}

(Adaptasi dari Dinas Pendidikan)

Berdasarkan rata- rata tersebut hasil tes kemampuan pemahaman konsep matematika tergolong cukup bagus, karena hasil tersebut melebihi KKM dari sekolah tersebut sebesar 75 tergolong kriteria baik. diperoleh sebanyak 20 subjek mendapatkan nilai diatas KKM dan 12 subjek dibawah KKM.

Selanjutnya kemampuan pemahaman konsep matematika Menurut Arikunto (2013) dapat dikualifikasikan sebagai berikut :

\begin{tabular}{cc}
$\begin{array}{c}\text { Tabel } 8 \text { Kualifikasi Pemahaman Konsep Matematika Siswa } \\
\text { Persentase (\%) }\end{array}$ & Kualifikasi Pemahaman Konsep \\
\hline $100-81$ & Sangat Tinggi \\
$80,99-61$ & Tinggi \\
$60,99-41$ & Cukup \\
\hline $40,99-21$ & Rendah \\
\hline $20,99-0$ & Sangat Rendah \\
\hline
\end{tabular}

Berikut merupakan presentasi hasil jawaban dari 32 subjek yang diteliti berdasarkan kategori jawaban benar dan salah :

Tabel 9 Persentasi Jawaban Subjek pada materi bangun ruang kubus dan balok

\begin{tabular}{lcccccccccc}
\multicolumn{1}{c}{ Kategori } & $\mathbf{1}$ & $\mathbf{2}$ & $\mathbf{3}$ & $\mathbf{4}$ & $\mathbf{5}$ & $\mathbf{6}$ & $\mathbf{7}$ & $\mathbf{8}$ & $\mathbf{9}$ & $\mathbf{1 0}$ \\
\hline \multirow{2}{*}{ Betul (\%) } & 100 & 94 & 100 & 63 & 69 & 63 & 69 & 68 & 88 & 59 \\
\hline Salah (\%) & 0 & 6 & 0 & 37 & 31 & 37 & 31 & 32 & 22 & 41 \\
\hline
\end{tabular}

Dari Tabe 8 dapat dilihat bahwa persentase kesalahan yang dilakukan subjek pada nomor 1 sampai dengan 10 sebesar $0 \%, 6 \%, 0 \%, 37 \%, 31 \%, 37 \%, 31 \%, 44 \%, 22 \%$, dan $28 \%$. dapat diamati rata-rata kesalahan yang dilakukan subjek yakni mencapai $24 \%$ tergolong rendah.

\section{Data Hasil Wawancara}

Wawancara yang digunakan pada penelitian ini adalah wawancara mengikat atau bersifat semi struktur, sehingga pertanyaan dapat dikembangkan secara tidak terstruktur 
sesuai dengan jawaban lisan dan perilaku siswa yang diwawancara. Wawancara ini dilakukan secara bergantian, sehingga peneliti dapat menyimpulkan kemampuan pemahaman konsep matematis dalam mengerjakan tiap butir soal pada materi Bangun Ruang kubus dan balok setelah menggunakan pembelajaran discovery learning.

\section{Hasil Penelitian}

Berdasarkan temuan penelitian, peneliti mengetahui hasil atau jawaban atas rumusan masalah yang telah disusun, yaitu tentang kemampuan pemahaman konsep matematis siswa dalam menyelesaikan soal volume kubus dan balok. Soal kubus dan balok yang dimaksud dalam penelitian ini terbatas pada soal tipe kemampuan pemahaman untuk siswa kelas V.2 disimpulkan bahwa mayoritas siswa mampu memahami konsep matematika diliat dari nilai yang diperoleh dengan presentase paham konsep sebanyak $76 \%$ tergolong kategori tinggi dan tingkah kesalahan yang dilakukan siswa tergolong rendah hanya mencapai $24 \%$. Pada penelitian ini salah satu tujuan penting dalam pembelajaran matematika adalah agar siswa dapat lebih mengerti tentang konsep materi yang diberikan. Sejalan dengan pendapat Novitasari (2016) "Kemampuan pemahaman adalah salah satu tujuan penting dalam pembelajaran matematika. Materi-materi yang diajarkan kepada siswa bukan hanya sebagai hapalan, melainkan untuk dipahami agar siswa dapat lebih mengerti konsep materi yang diberikan."

Berdasarkan temuan peneliti yang didapat dari wawancara perwakilan siswa dan Guru matematika, diatas dapat disimpulkan bahwa penyebab banyak siswa yang tidak menjabarkan apa saja yang diketahui dan ditanyakan pada soal soal cerita diatas bukan berarti siswa tidak paham, ketika peneliti tanya sejujurnya siswa mengerti hanya saja beberapa faktor yang mempengaruhi tahap ini tidak tampak jelas yaitu seperti siswa cenderung terburu-buru (Hastuti et al., 2021; Kosiret et al., 2021). Hal ini dapat dibuktikan pada beberapa penggalan percakapan wawancara tersebut. dapat disimpulkan bahwa untuk tahap pemahaman konsep pertanyaan sebagian besar siswa dapat memahami informasi yang terkandung dalam soal hanya saja masih ada beberapa siswa yang hanya paham tetapi tidak diungkapkan di penulisan dikarenakan beberapa faktor(Ikram \& Ikram, 2021; Satriawati et al., 2018; Subhi et al., 2020).

Salah satu faktor penyebabnya yaitu siswa cenderung tergesa-gesa menjawab karena durasi waktu, takut yang terlintas ingat tiba-tiba lupa jika tidak langsung ditulis, atau malas dan pengen cepat-cepat selesai. Tetapi dari pemaparan di atas tampak bahwa secara keseluruhan siswa sudah mampu menentukan hal-hal yang diketahui dan yang ditanyakan dari soal tersebut. Selain itu, siswa juga mampu memahami hubungan antar informasi yang diberikan. 
Dilihat dari beberapa indikator antara lain Kemampuan pemahaman konsep siswa. sebanyak 20 Subjek memperoleh nilai diatas 75 mewakili kategori kemampuan pemahaman konsep matematika tinggi dapat menguasai lima indikator kemampuan pemahaman konsep, yaitu (1) menggunaka jarring-jaring, dan simbol-simbol untuk mempresentasikan suatu konsep, (2) mengidentifikasi membuat contoh dan bukan contoh, (3) mengubah suatu bentuk representasi ke bentuk lain, (4) mengidentifikasi sifat-sifat suatu konsep, (5) membandingkan dan membedakan konsep-konsep, dan (6) mengenal syarat-syarat yang menentukan suatu konsep. Dan sebanyak 12 subjek memperoleh nilai dibawah 75 mewakili kategori kemampuan pemahaman konsep matematika rendah dapat menguasai tiga indikator kemampuan pemahaman konsep, yaitu (1) mengidentifikasi membuat contoh dan bukan contoh, (2) mengubah suatu bentuk representasi ke bentuk lain, dan (3) membandingkan dan membedakan konsep-konsep(Carraher et al., 2008).

Beberapa faktor-faktor yang mempengaruhi tingkat kemampuan pemahaman konsep siswa untuk siswa yang memiliki kemampuan konsep tinggi, yaitu mereka memiliki motivasi belajar yang tinggi, lebih antusias dan aktif dalam proses pembelajaran, menguasai penjumlahan, perkalian, dan pembagian, serta mampu menyelesaikan tes yang berkaitan dengan pembelajaran. sedangkan, untuk siswa yang memiliki kemampuan pemahaman konsep rendah disebabkan karena mereka tidak memiliki motivasi untuk belajar, malas mengikuti proses pembelajaran, tidak bisa mengerjakan tes yang diberikan, dan tidak menguasai penjumlahan, perkalian dan pembagian(Alshurideh et al., 2020; Cheon et al., 2012; Gagatsis et al., 2004).

Berdasarkan hasil penelitian tingkat pemahaman konsep matematika siswa kelas $\mathrm{V}$ MI Attaqwa 28 Kota Bekasi, dilihat dari hasil tes yang diberikan dan informasi yang didapat dari Guru matematika serta siswa dapat disimpulkan bahwa tingkat pemahaman konsep matematisnya tergolong kategori Tinggi dengan presentase paham konsep sebanyak 76\%, dengan persentase rata-rata kesalahan yang dilakukan subjek 24\%. Begitu juga penelitian yang dilakukan Mutmainna, dkk (2018) Pada siswa kelas XII MAN 1 Makassar pada semester ganjil tahun ajaran 2016/2017. Dengan Penelitian Research \& Development $(R \& D)$ dengan menggunakan model pengembangan Tessmer yang dikenal dengan tipe formatif evaluation, Diketahui bahwa jumlah siswa yang tegolong tinggi dalam kategori paham konsep 58,95\%, persentase siswa yang mengalami miskonsepsi sebesar $12,63 \%$ dan persentase siswa yang tidak paham konsep sebesar $28,25 \%$.

\section{KESIMPULAN}


ISSN: $\quad 2775-8435$ (Online) 2776-2726 (Print) Journal homepage: https://journal.uhamka.ac.id/index.php/ijopme Berdasarkan hasil penelitian dan analisis, maka peneliti menarik simpulan bahwa tingkat

Pemahaman Konsep Matematika siswa kelas V MI Attaqwa 28 Kota Bekasi pada pokok bahasan Bangun Ruang Kubus dan Balok Tahun Pelajaran 2020/2021 tergolong kategori tinggi dengan mayoritas siswa mampu memahami konsep matematika diliat dari nilai yang diperoleh dengan presentase paham konsep sebanyak $76 \%$ dan tingkah kesalahan yang dilakukan siswa tergolong rendah hanya mencapai $24 \%$ Tergolong kategori tinggi dengan presentase paham konsep sebanyak $76 \%$, beberapa faktor penyebabnya yaitu siswa dapat menyebutkan contoh konkrit benda yang berbentuk balok dan kubus yang ada disekitar, siswa dapat membuat jaring-jaring kubus dan balok dengan benar, dan siswa dapat menyelesaikan soal volume kubus dan balok yang sesuai permasalahan-permasalahan dalam kehidupan nyata dengan konsep yang benar, serta banyaknya siswa yang memiliki motivasi belajar yang tinggi, lebih antusias dan aktif dalam proses pembelajaran jarak jauh, menguasai penjumlahan, perkalian, dan pembagian, serta mampu menyelesaikan tes yang berkaitan dengan pembelajaran kubus dan balok.

\author{
Identitas Penulis \\ Huri Suhendri | \\ Email: fadillah.ike03@gmail.com \\ ORCID ID: \\ Ike Fadilah \\ Email: : huri.suhenderi@unindra.ac.id \\ ORCID ID:
}

\title{
Conflict of Interest
}

The authors state there is no conflict of interest

\section{Citation information}

Cite this article as: Suhendri, H., \& Fadilah, I,. K Analisis Kemampuan Pemahaman Konsep Matematis Siswa Kelas V Pada Materi Kubus Dan Balok. International Journal of Progressive Mathematics Education. 1(2). 161-183. https://doi.org/10.22236/ijopme.v1i1.7308

\section{REFERENSI}

Alshurideh, M., Al Kurdi, B., Salloum, S. A., Arpaci, I., \& Al-Emran, M. (2020). Predicting the actual use of m-learning systems: a comparative approach using PLS-SEM and machine learning algorithms. Interactive Learning Environments, $0(0)$, 115. https://doi.org/10.1080/10494820.2020.1826982 
Aprilyani, N., \& Hakim, A. R. (2020). Pengaruh Pembelajaran Assurance, Relevance, Interest, Assessment, Satisfaction Berbantuan Etnomatematika terhadap Kemampuan Pemecahan Masalah. JNPM (Jurnal Nasional Pendidikan Matematika), 4(1), 61. https://doi.org/10.33603/jnpm.v4i1.2549

Ariyanto, L., Aditya, D., \& Dwijayanti, I. (2019). Pengembangan Android Apps Berbasis Discovery Learning Untuk Meningkatkan Pemahaman Konsep Matematis Siswa Kelas VII. Edumatika: Jurnal Riset Pendidikan Matematika, 2(1), 40. https://doi.org/10.32939/ejrpm.v2i1.355

Carraher, D. W., Martinez, M. V., \& Schliemann, A. D. (2008). Early algebra and mathematical generalization. ZDM - International Journal on Mathematics Education, 40(1), 322. https://doi.org/10.1007/s11858-007-0067-7

Cheon, J., Lee, S., Crooks, S. M., \& Song, J. (2012). An investigation of mobile learning readiness in higher education based on the theory of planned behavior. Computers and Education, 59(3), 1054-1064. https://doi.org/10.1016/j.compedu.2012.04.015

Ferri, R. B. (2006). Theoretical and empirical differentiations of phases in the modelling process. ZDM - International Journal on Mathematics Education, 38(2), 8695. https://doi.org/10.1007/BF02655883

Gagatsis, A., Christou, C., \& Elia, I. (2004). The Nature of Multiple Representations in Developing Mathematical Relationships. Quaderni Di Ricerca in Didattica, 14(1), 150-159.

Galbraith, P., \& Stillman, G. (2006). A framework for identifying student blockages during transitions in the modelling process. ZDM - International Journal on Mathematics Education, 38(2), 143-162. https://doi.org/10.1007/BF02655886

García, F. J., \& Bosch, M. (2006). Mathematical modelling as a tool for the connection of school mathematics. ZDM - International Journal on Mathematics Education, 38(3), 226246. https://doi.org/10.1007/BF02652807

Hajar, S., \& Mulyani, S. R. (2017). Analisis Kajian Teoritis Perbedaan, Persamaan dan Inklusi Dalam Pelayanan Pendidikan Dasar Bagi Anak Berkebutuhan Khusus. Jurnal IImiah Mitra Swara Ganesha, 4(2), 48.

Hastuti, E. S., Eclarin, L., \& Dalam, K. K. S. (2021). Kecemasan Siswa Sekolah Menengah Pertama Menyelesaikan Masalah SPLDV Pada Kelas Virtual Dalam. International Journal of Progressive Mathematics Education, 1(1), 6484. https://doi.org/10.22236/ijopme.v1i1.6914

Hevriansyah, P., \& Megawanti, P. (2017). Pengaruh Kemampuan Awal terhadap Hasil Belajar Matematika. JKPM (Jurnal Kajian Pendidikan Matematika), 2(1), 37. https://doi.org/10.30998/jkpm.v2i1.1893 
Ikram, M., \& Ikram, M. (2021). Analysis of The Occurrence of Reversible Reasoning for Inverse Cases: A Case Study on The Subject Adjie. International Journal of Progressive Mathematics Education, 8435(1), 1-15. https://doi.org/10.22236/ijopme.v1i1.6635 To

Kosiret, A., Indiyah, F. H., \& Wijayanti, D. A. (2021). The Use of Generative Learning Model in Improving Students' Understanding of Mathematical Concepts of Al-Azhar 19 Islamic High School. International Journal of Progressive Mathematics Education, 1(1), 1626. https://doi.org/10.22236/ijopme.v1i1.6593

Lean, G., \& Clements, M. A. (Ken. (1981). Spatial ability, visual imagery, and mathematical performance. Educational Studies in Mathematics, 12(3), 267299. https://doi.org/10.1007/BF00311060

Maracci, M. (2008). Combining different theoretical perspectives for analyzing students' difficulties in vector spaces theory. ZDM - International Journal on Mathematics Education, 40(2), 265-276. https://doi.org/10.1007/s11858-008-0078-z

Muhandaz, R., Trisnawita, O., \& Risnawati, R. (2018). Pengaruh Model Pembelajaran Course Review Horay terhadap Kemampuan Pemahaman Konsep Matematis Berdasarkan Kemandirian Belajar Siswa SMK Pekanbaru. JURING (Journal for Research in Mathematics Learning), 1(2), 137. https://doi.org/10.24014/juring.v1i2.6552

Mutia, M. (2017). Analisis Kesulitan Siswa SMP dalam Memahami Konsep Kubus Balok dan Alternatif Pemecahannya. Beta Jurnal Tadris Matematika, 10(1), 83. https://doi.org/10.20414/betajtm.v10i1.107

Mutmainna, D., Mania, S., \& Sriyanti, A. (2018). Pengembangan Instrumen Tes Diagnostik Pilihan Ganda Dua Tingkat Untuk Mengidentifikasi Pemahaman Konsep Matematika. MaPan, 6(1), 56-69. https://doi.org/10.24252/mapan.2018v6n1a6

Nahdi, D. S. (2017). Implementasi Model Pembelajaran Collaborative Problem Solving untuk Meningkatkan Kemampuan Representasi Matematis Siswa Sekolah Dasar. Jurnal Cakrawala Pendas, 3(1).

Novitasari, D. (2016). Pengaruh Penggunaan Multimedia Interaktif Terhadap Kemampuan Pemahaman Konsep Matematis Siswa. FIBONACCI: Jurnal Pendidikan Matematika Dan Matematika, 2(2), 8. https://doi.org/10.24853/fbc.2.2.8-18

Radford, L. (2008). Connecting theories in mathematics education: challenges and possibilities. ZDM - Mathematics Education, 40(2), 317-327. https://doi.org/10.1007/s11858-008$\underline{0090-3}$

Satriawati, G., Musyrifah, E., \& Purwanto, S. (2018). Pengaruh Strategi Pembelajaran Active Knowledge Sharing t terhadap Kemampuan Komunikasi Matematik Siswa. Jurnal Riset Pendidikan Matematika, 1(1), journal.unj.ac.id/unj/index.php/jrpmj/article/download/4961/3659 
Scheffer, M., \& Markus, K. (2016). Analisis kesalahan dalam menyelesaikan soal matematika Materi Bangun Ruang Sisi Datar Kubus dan Balok pada Siswa Kelas VIII. Repositori Universitas PGRI Yogyakarta, 3345-3356.

Sorvo, R., Koponen, T., Viholainen, H., Aro, T., Räikkönen, E., Peura, P., Dowker, A., \& Aro, M. (2017). Math anxiety and its relationship with basic arithmetic skills among primary school children. British Journal of Educational Psychology, 87(3), 309327. https://doi.org/10.1111/bjep.12151

Subhi, S. M., Nursuprianah, I., \& Izzati, N. (2020). Pengaruh Pembelajaran Matematika Al-Qur'an dengan Model Pembelajaran Kooperatif Tipe Think Pair Share Terhadap Kemampuan Komunikasi Matematis Siswa. Jurnal Riset Pendidikan Matematika Jakarta, 2(2), 112. https://doi.org/10.21009/jrpmj.v2i1.16207

Tan, M. (2018). When Makerspaces Meet School: Negotiating Tensions Between Instruction and Construction. Journal of Science Education and Technology, 7589. https://doi.org/10.1007/s10956-018-9749-x

Umam, K., Nusantara, T., Parta, I. N., Hidayanto, E., \& Mulyono, H. (2019). An Application of Flipped Classroom in Mathematics Teacher Education Programme. International Journal of Interactive Mobile Technologies (IJIM), 13(03), 68. https://doi.org/10.3991/ijim.v13i03.10207

Villela, lucia maria aversa. (2020). Metode Peneitian Kualitatif dan Kuantitatif. In Journal of Chemical Information and Modeling (Vol. 53, Issue 9).

Zulhamma, R. (2020). Analisis Kemampuan Siswa Dalam Menyelesaikan Soal Bangun Ruang Sisi Datar. LEMMA: Letters Of Mathematics Education, 6(2), 313322. https://doi.org/10.22202/jl.2020.v6i2.3379 